\title{
ASPECTOS DO ENSINO RELIGIOSO NO BRASIL: PERSPECTIVAS PARA UM TEMPO SOMBRIO ${ }^{1}$
}

\section{Aspects of religious education in Brazil: prospects dor a gloomy weather}

\author{
Fabrino da Rocha Cólli ${ }^{2}$ \\ Paulo Jonas dos Santos Júnior ${ }^{3}$ \\ Silvana Duarte Gonçalves dos Santos 4 \\ Edeson dos Anjos Silva 5
}

\begin{abstract}
Resumo:
O presente artigo relata o cenário de adaptação do ensino religioso às pluralidades e aos desafios dos dias atuais. Essa disciplina precisou se adequar a um cenário em que o exame multidisciplinar se mostra como imprescindível à elucidação de discussões. Ao longo do texto foi analisado a Lei de Diretrizes e Bases da Educação Nacional e, eventualmente, intenções políticas e ideológicas, como também o recente julgamento da Ação Direta de Inconstitucionalidade do Supremo Tribunal Federal Brasileiro, que manteve o ensino religioso confessional nas escolas públicas. Por fim, a partir deste estudo foi possível analisar que o ensino religioso escolar, se aplicado a partir das verdadeiras bases de igualdade e laicidade, e a pautado em uma reflexão advinda das Ciências das Religiões, pode colaborar para que o aluno compreenda que o respeito aos mais diversificados princípios de religiosidade e fé é de suma importância para a construção de uma sociedade melhor.
\end{abstract}

Palavras-Chave: Ensino Religioso; Educação; Legislação.

\section{Abstract:}

This article reports the scenario of adaptation of religious education to the pluralities and challenges of today. This discipline needed to adapt to a scenario in which the multidisciplinary examination is shown to be essential to the elucidation of discussions. Throughout the text, the Law of Guidelines and Bases of National Education and, eventually, political and ideological intentions were analyzed, as well as the recent judgment of the Direct Action of

1 Submetido em: 08.06.2020. Aceito em: 19.09.2020

2 Graduação em Direito. Graduando em Pedagogia e Teologia. Especialização em Direito e Teologia. Mestrando em Ciências das Religiões na Faculdade Unida de Vitória, ES. Contato: fabri collii@ hotmail.com

3 Graduação em Teologia e História. Especialização em Docência do Ensino Superior, História e Filosofia, Filosofia e Sociologia, Ensino Religioso e Artes, História e Cultura no Brasil. Mestrado em Ciências das Religiões pela Faculdade Unida de Vitória. Doutorado em Planejamento Regional e Gestão da Cidade pela UCAM, RJ. Contato: paulojsjunior@hotmail.com

4 Graduação em Letras e Teologia. Especialização em Língua Portuguesa, Psicopedagogia e Ciências da Religião. Contato: silvanadgsantos@ hotmail.com

5 Graduação em Ciências e Matemática. Especialização em Docência do Ensino Superior, Metodologia no Ensino, Educação Inclusiva, Filosofia e Sociologia. Mestrado em Ciências das Religiões pela Faculdade Unida de Vitória, ES. Contato: edanjos@ hotmail.com 
Unconstitutionality of the Brazilian Supreme Court, which maintained religious confessional teaching in public schools. Finally, from this study it was possible to analyze that the religious school education, if applied from the true bases of equality and secularity, and guided by a reflection coming from the Sciences of Religions, can collaborate for the student to understand that respect to the most diversified principles of religiosity and faith it is extremely important for the construction of a better society.

Key words: Religious Education; Education; Legislation.

\section{Introdução}

A Igreja e o Estado sempre caminharam juntos e chegaram, até mesmo, a ser confundidos em um só poder. ${ }^{6}$ Durante o período monárquico havia muitos padres legisladores, num total de quinze na Assembleia Constituinte de $1822 .{ }^{7} \mathrm{Em}$ Cartas anteriores à de 1891 o Estado era confessional, a exemplo da Carta de 1824 de Independência do Brasil, em que o Império tinha a religião católica como oficial. Todos os servidores públicos deveriam que ser oficialmente católicos e a política se misturava com o clero. ${ }^{8}$ Em 1891, o Estado se tornou laico, a Igreja foi separada do Estado e foi decretado o fim do padroado no Brasil, que outorgado pela Santa Sé possibilitava domínio direto da coroa nas negociações religiosas; a exemplo de cleros e bispos que eram também funcionários da coroa. ${ }^{9}$ Contudo, o ensino religioso continuou sendo ministrado nas escolas públicas, de forma facultativa, porém confessional. ${ }^{10}$

Esse processo de laicização do Estado brasileiro, todavia nunca se deu de fato, mesmo após a última constituinte. Pelo contrário, as igrejas continuaram manifestando seu poder político pelo "voto de obediência", como no caso da então Liga Eleitoral Católica e, agora, também com a abertura para as religiões protestantes que exerceram força política através da Frente Parlamentar Evangélica. ${ }^{11}$ A Constituição de 1934, e as seguintes, invocaram em seus preâmbulos o nome do Deus cristão. Por outro lado, com o governo militar, Estado Novo de Getúlio Vargas, o Estado brasileiro, entre 1964 e 1985, promoveu um chamamento em todo o país para o cumprimento de deveres cívicos e patrióticos, sobretudo nas escolas, com o ensino da educação moral cívica.

6 SANTOS JÚNIOR, Paulo Jonas dos. A Religiosa no Currículo de Filosofia do Estado do Espirito Santo e sua Prática Docente. 2016. 92 f. Dissertação (Mestrado) - Curso de Ciências das Religiões, Faculdade Unida de Vitória, Vitoria, 2016, p. 37.

7 FIGUEIREDO, Anísia de Paulo. O ensino religioso no Brasil; tendências, conquistas e perspectivas. Petrópolis: Vozes, 1996, p. 19. "Os primeiros passos na formação do povo brasileiro são dados em tempos fortes de exploração de riquezas da terra e de submissão dos nativos aos esquemas da metrópole. O Brasil desde o início é alvo de uma política mercantilista sob o regime do monopólio, que exige estabelecimento de um pacto colonial".

8 FIGUEIREDO, 1996, p. 20.

9 RUEDELL, Pedro. Evolução do Ensino Religioso nas escolas oficiais do Rio Grande do Sul. São Leopoldo: UNISINOS, 2007, p. 18.

10 RUEDELL, 2007, p. 19.

11 Mais tarde conhecida como "bancada evangélica". SYLVESTRE, Josué. Irmão vota em irmão: Os evangélicos, A Constituinte e a Bíblia. Brasília: Pergaminho, 1986, p. 21.

Protestantismo em Revista | São Leopoldo | v. 46, n. 01 | p. 98-109| Jan./jun. 2020

Disponível em: <http://periodicos.est.edu.br/index.php/nepp> 
A tentativa de adequar o comportamento da sociedade a um padrão social/moral que estava sendo construído pelo Estado fez surgir o ensino da Educação Moral Cívica, uma doutrina elaborada ao lado da Segurança Nacional que fazia parte do projeto de construção de um "BRASIL GRANDE" ou "BRASIL POTÊNCIA", 12 tal como desejavam os militares. Há nesse cenário uma contraposição a um padrão até então ocupado pela Igreja na construção da educação e moral do cidadão; isso envolto de um retorno ao patriotismo, desfiles cívicos, delação de vizinhos subversivos, e da doutrina do escutar sem questionar as autoridades. ${ }^{13}$

Assim, o presente artigo, a partir de uma pesquisa de base bibliográfica, busca compreender como o Ensino Religioso Escolar tem se comportado ao longo da história do país, uma vez que sua origem diferenciada possibilita ao docente a aplicação dos mais diversificados métodos de ensino.

\section{A influência da religião na sociedade}

O contexto sócio-político, cultural e religioso no Brasil tem passado por mudanças rápidas e significativas nesses últimos anos. Se traçarmos um paralelo histórico-cultural dos anos 1980 até os dias atuais, nos depararemos com uma mudança radical na forma de como a sociedade lida com o ensino, o trabalho, a cultura e a religião. ${ }^{14}$ Desde os tempos mais remotos, a religião tem ocupado um lugar cativo na humanidade ${ }^{15}$. Antigos reis usaram-na para consolidar sua condição de homem-divindade; imperadores se aliaram à religião para serem adorados e, assim, temidos pelos homens, e quando não conseguiam um lugar entre os deuses, eram pelo menos apoiados pelo clero. ${ }^{16}$ Dessa perspectiva Rousseau, em sua obra "Do Contrato Social", escreve: "os homens, de início, não tiveram outros reis senão os deuses, nem outro governo, a não ser o teocrático"17.

Porém, após a Reforma Protestante, ${ }^{18}$ a descoberta do novo continente ${ }^{19}$, a Revolução Industrial ${ }^{20}$ e o início das ciências modernas, ${ }^{21}$ alguns pensadores chegaram a proclamar o fim da religião. Voltaire, por exemplo, disse que "dentro de 100 anos, a Bíblia e o

12 Frases de impacto utilizadas em propagandas em diversos veículos de comunicação durante o governo militar. RUEDELL, 2007, p. 19.

13 FIGUEIREDO, 1996, p. 17.

14 OLIVEIRA, Pérsio Santos. Introdução à Sociologia. São Paulo: Ática, 2001, p. 179.

15 OLIVEIRA, 2001, p. 169.

16 CHAUÍ, Marilena. Iniciação à Filosofia. 2. ed. São Paulo: Ática, 2014, p. 3.

17 ROUSSEAU, Jean Jacques. Do contrato social. 2 ed. Leme: EDIJUR, 2013, p. 154.

18 A Reforma Protestante eclodiu no dia 31 de outubro de 1517, e dividiu o Cristianismo entre Católicos e Protestantes. Enquanto os Católicos se mantiveram fiéis ao Papado, os Protestantes proclamaram que a fé deve ser cultivada a partir do livre exame da Bíblia. SANTOS JÚNIOR, 2016, p. 31.

19 Oficialmente esse termo se refere ao momento em que o navegador Cristóvão Colombo chegou no Continente Americano, em especial nas Bahamas em 12 de outubro de 1492. MONDIN, Battista. Curso de Filosofia. 10. ed. São Paulo: Paulus, 2006, p.15.

20 De acordo com as Ciências Históricas, a Revolução Industrial foi uma fase de transição dos processos de produção que teve início na Inglaterra. Essa transformação marcou a migração da produção manual para a produção executada por máquinas, e ocorreu nos séculos XVIII e XIX. MONDIN, 2006, p.15.

21 A partir da Idade Moderna vários filósofos e estudiosos romperam com o pensamento tradicional da Idade Média, que defendia um ideal teocêntrico. Assim, a ciência ganhou autonomia, uma vez que suas conclusões passaram a ser independentes. SANTOS JÚNIOR, Paulo Jonas dos; ROSA, André Luis da. Experiência religiosa: da Reforma Protestante ao avivamento pentecostal. Encontros Teológicos: Reforma ontem e hoje, Florianópolis, v. 31, n. 2, p.235-252, ago. 2016. Disponível em: <facasc.edu.br>. Acesso em: 05 abr. 2020.

Protestantismo em Revista | São Leopoldo | v. 46, n. 01 | p. 98-109| Jan./jun. 2020

Disponível em: <http://periodicos.est.edu.br/index.php/nepp> 
Cristianismo serão varridos da existência e passarão à história". ${ }^{22}$ Isso levou o homem a acreditar que apenas o conhecimento das ciências exatas seria necessário. Porém o tempo passou e a religião continua a influenciar a humanidade ${ }^{23}$.

Em tempos de colonialismo, as regiões que dominavam a erudição regiam seus subjugados sem dar fim à cultura local, entretanto povos sem essa maestria aniquilavam seus dominados, determinando-lhes seus particulares costumes em prejuízo às crenças locais. Nesses casos, a religião assumia um papel relevante, pois através dela o conquistador acreditava ter a oportunidade de levar a palavra de Deus aos bárbaros; geralmente o povo conquistado precisava usar de artifícios para preservar suas antigas crenças. ${ }^{24}$

Em nosso solo, a religião sempre influenciou a população e, desde os registros feitos a partir da presença portuguesa, ela se confunde com a cultura, sendo absorvida pelo modo de vida brasileiro ${ }^{25}$. O Brasil colônia é caracterizado por um estreito relacionamento entre a Monarquia e a religião Católica Romana. ${ }^{26}$ Com isso, os monarcas eram verdadeiros representantes de Deus na terra, sendo compromissados não apenas a expandir o império, mas também a implantar a religião católica. Por conveniência, os líderes da igreja davam aos monarcas plenos poderes na administração eclesiástica. ${ }^{27}$

Em 1822, a liberdade religiosa apareceu como tema, ganhando impulso após a proclamação da Independência e, a despeito de ratificar a associação entre o Estado e a Igreja, a Constituição de 1824 manifestava certa tolerância religiosa. Seus artigos demonstram que não podia haver mais perseguição, entretanto o cidadão não católico ainda amargava rejeição. Comparada com o período colonial, no entanto, em que a Igreja Católica devastou a civilização indígena, demonstrando falta de respeito e arrogância, como se a cultura europeia fosse a única válida, isso representava um grande avanço, pois desde então a religião não era mais imposta aos sujeitos, que se tornaram autônomos para terem sua própria opção religiosa. ${ }^{28}$

O período republicano também foi importante no avanço das conquistas dos direitos de liberdade religiosa. O Decreto no 119-A de 7 de janeiro de 1890, de Ruy Barbosa, trazia, em seus artigos, diversos avanços no que diz respeito à liberdade religiosa. ${ }^{29}$ Esse decreto marcou a história do país, pois, em 390 anos de presença portuguesa, essa foi a primeira vez que Estado e religião estavam separados legalmente em solo brasileiro. Por fim, a constituição de 1988 selou a liberdade religiosa e de culto. Isso pode ser constatado em diversos artigos que abrem ao cidadão a possibilidade de expressar livremente sua fé. ${ }^{30}$

Dessa forma, pode-se observar que o catolicismo embasou a formação da sociedade brasileira. ${ }^{31}$ Observamos, entretanto, que com o decorrer do tempo, houve um declínio do

22 GEISLER, Norman L.; NIX, William E. A General Introduction to the Bible. Chicago: Hardcover, 1986, p. 123.

23 OLIVEIRA, 1998, p. 169.

24 CALMON, Pedro. História Social do Brasil: Espírito da Sociedade Colonial. São Paulo: Martins Fontes, 2010, p.12.

25 PIERUCCI, 2012, p. 93.

26 PIERUCCI, 2012, p. 91.

27 CALMON, 2010, p.12.

28 CALMON, 2010, p.12.

29 BRASIL. Decreto Federal no 119-a de 1890. Disponível em: <http://www.planalto.gov.br/ccivil_03/decreto/1851-1899/d119-a.htm>. Acesso em: 01 mai. 2020.

30 BRASIL. Constituição - Federal (1988). Disponível

PIERUCCI, 2012, p. 88.

Protestantismo em Revista | São Leopoldo | v. 46, n. 01 | p. 98-109| Jan./jun. 2020

Disponível em: <http://periodicos.est.edu.br/index.php/nepp> 
domínio da religião Católica Romana, embora a população brasileira tenha continuado a ser predominantemente religiosa ${ }^{32}$. Assim, o monopólio Católico Romano já não faz mais parte da realidade brasileira, mas isso não significa que nosso país esteja deixando a religião de lado, pois como o próprio censo aponta, pelo menos $90 \%$ dos brasileiros professam uma fé. ${ }^{33}$ O que mudou em relação ao passado é que hoje há uma pluralidade religiosa como nunca antes. ${ }^{34}$

Sendo inegável a herança religiosa que nos foi deixada, é possível, ainda hoje, observar que a religião se faz presente em diversos aspectos da sociedade, misturando-se, em muitos casos, com nosso modo de vida, e diversas vezes se passando como algo cultural, ou seja, não sendo mais encarado como religioso por grande parte da população. ${ }^{35}$ Para essa discussão, sobre assuntos de natureza religiosa tratados pela sociedade como culturais, é importante verificar o conceito de secularização. Sobre isso, Harvey Cox, na obra "A Cidade Secular", analisa as principais dimensões da secularização a partir da perspectiva cristã. ${ }^{36}$ Sobre o processo de secularização, o autor escreve:

\begin{abstract}
Secularização como um termo descritivo tem uma significação larga e inclusiva. Surge sob diferentes aspectos, dependendo da história religiosa e política da área considerada. Mas onde quer que apareça, deve ser cuidadosamente distinguida de secularismo. A secularização implica um processo histórico, quase que certamente irreversível, no qual a sociedade e a cultura são libertadas da tutela do controle religioso e das concepções metafísicas rígidas do mundo. Temos dito que se trata de um acontecimento basicamente libertatório (...). A secularização surge, em larga medida, da influência formativa da fé bíblica sobre o mundo, influência esta veiculada primeiramente pela igreja cristã e, mais tarde, pelos movimentos em parte derivados dela. ${ }^{37}$
\end{abstract}

Sobre esse assunto, segundo Morin, há uma tendência de afastamento entre as disciplinas, que acabam em se fechar e não comunicar umas com as outras e, dessa maneira, fortalecem uma tradição científica tipicamente disciplinar. ${ }^{38} \mathrm{~A}$ temática da influência religiosa no atual contexto se faz necessária para se obter uma perspectiva que englobe as dimensões humanas diferentes que as restritas ao ambiente de culto. Aproximar as Ciências das Religiões com os outros ramos das ciências não ocorre sem atrito, inclusive porque cada uma das ciências tem suas próprias formas de fechamento disciplinar. ${ }^{39}$ Essa carência de entendimento da relação entre a religião e a sociedade secular foi consolidada a partir de acontecimentos como a Reforma Protestante, em especial, a partir do lluminismo e da Revolução Industrial, que trouxe o crescente fortalecimento das Ciências Naturais e a gradativa desvinculação de

32 INSTITUTO DATAFOLHA DE PESQUISAS. Levantamento das religiões brasileiras. Disponível em: <http://datafolha.folha.uol.com.br/opiniaopublica/2013/09/138655096-mudanca-de-cenarioreligioso.shtml>. Acesso em: 02 fev. 2020.

33 INSTITUTO DATAFOLHA DE PESQUISAS. Cenário religioso nacional. Disponível em: <http://datafolha.folha.uol.com.br/opiniaopublica/2013/07/1314857-fatia-de-catolicos-e-a-menor-emduasdecadas.shtml>. Acesso em: 02 fev. 2020.

34 PIERUCCI, 2012, p. 89.

35 COX, Harvey. A Cidade Secular: a secularização e a urbanização na perspectiva teológica. Santo André - SP: Academia Cristã, 2015, p. 24.

36 COX, 2015, p.17.

37 COX, 2015, p.17.

38 MORIN, Edgar. Introdução ao pensamento complexo. Porto Alegre: Sulina, 2005, p. 11.

39 MORIN, 2005, p.13.

Protestantismo em Revista | São Leopoldo | v. 46, n. 01 | p. 98-109| Jan./jun. 2020

Disponível em: <http://periodicos.est.edu.br/index.php/nepp> 
tudo que tem ligação com o sagrado e o religioso. Em meados do século XIX, alguns teóricos chegaram a proclamar que, no século XXI, aconteceria o fim da religião. ${ }^{40}$

Segundo Edgar Morin, a ordenação disciplinar disjuntor-redutor, vastamente utilizada, baseia-se nesse entendimento, que se caracterizou por separar as categorias e as disciplinas e, destarte, por fazer da distinção um processo de fragmentação, de disjunção, sem interação entre partes separadas; enquanto, por outro lado, reduzia o sistemático ao simples (o humano ao nível biológico, este ao nível físico e químico, etc.). Esse tipo de conhecimento científico, baseado em métodos simplificadores, disjuntivos e reducionistas, é para o epistemólogo e sociólogo francês, uma tendência que produz mais cegueira do que elucidação, ou seja, "mutila as realidades e os fenômenos explicados na tentativa de controle e dominação". ${ }^{41}$

A referida desarticulação, que "separa o físico do biológico, separa as categorias, as disciplinas" 42 , perdurou por um longo período da história da ciência e ainda persiste como prática da ocupação científica contemporânea e influencia negativamente na busca por soluções para a problemática social ${ }^{43}$. Em virtude dessa tendência que direcionou as questões religiosas às margens da Teologia (dissociada do campo das Ciências Sociais), é possível considerar que o tardio tratamento da temática pela Sociologia tem um fundamento histórico.

Desde o seu surgimento, a Ciência Social - que surgiu muito próxima ao advento industrialista do século XVIII - esteve centrada na discussão em torno do progresso e da racionalidade humana na modernidade e, em época de ascensão renascentista, o que menos se queria era voltar às "prisões religiosas". ${ }^{44}$ A carência investigativa sobre esse tema foi caracterizada antes do período clássico da Sociologia, pelo modo superficial como foi investigada. Porém, contrariando as expectativas iluministas, o século XXI chegou e a religião não se extinguiu. Pelo contrário, no continente americano surge um grande avivamento do cristianismo, em especial, o ramo pentecostal, que se estabelece na América Latina onde ganha impulso e se espalha para todo o planeta.

O despertamento espiritual que sacudiu o mundo religioso no período compreendido entre o final do século XIX e o início do século XX, teve sua provável origem na Europa, e um dos seguimentos do protestantismo que mais contribuiu para isso foi, certamente, o então representado pelos morávios, pois avivamento espiritual e missões são características intimamente ligadas a história desse povo. Oriundo de uma região da antiga Tchecoslováquia, os morávios, mesmo não sendo significativamente numerosos, bem cedo ficaram conhecidos em toda a Europa e em muitas outras partes do mundo por sua piedade, experiência de comunhão com Deus e espírito missionário. (...) Em 1727 porém, cinco anos depois da chegada dos primeiros refugiados, toda a atmosfera mudou. Um período de renovação espiritual chegou ao clímax em um culto de comunhão a 13 de agosto com um grande reavivamento que, segundo os participantes, marcou a chegada do Espírito Santo em Herrnhut (...). Os morávios passaram, algum tempo depois, a desempenhar um importante papel no campo das missões. Levaram a mensagem de Cristo às Ilhas Virgens, Groenlândia, América do Norte, Lapônia, América do Sul (notadamente no Suriname), África do Sul, Índias ocidental e oriental, etc. Para a América do Norte,

40 GEISLER, 1986, p.123.

41 MORIN, 2005, p.13.

42 MORIN, 2005, p.13.

43 MORIN, 2005, p.11.

44 OLIVEIRA, 2001, p. 226.

Protestantismo em Revista | São Leopoldo | v. 46, n. 01 | p. 98-109| Jan./jun. 2020

Disponível em: <http://periodicos.est.edu.br/index.php/nepp> 
Zinzendorf não só enviou missionários; ele próprio esteve lá, tendo contribuído também para que esse país se tornasse mais tarde, um grande celeiro de missionários. ${ }^{45}$

Com o retorno da religião ao foco da pesquisa social e o constante crescimento de sua importância, o sentimento que aclamava o fim da ideia de sagrado norteando as ações humanas, que reinou nos séculos XVII, XVIII e XIX perde espaço e a temática religiosa começa a se reincorporar na vida dos cidadãos do século XX. ${ }^{46}$ Assim, a expansão do foco investigativo da religião pôde romper com a tradição simplista imposta pelo determinismo histórico e inserir-se no entendimento dos debates tidos como relevantes à vida social humana. Tal debate foi impulsionado devido à dedicação de importantes sociólogos ao tema. De uma ameaça aos progressos humanos no fim da Idade Média, a religião passou a ser analisada, respeitada e valorizada como parte integrante do processo social humano. Esse novo foco culminou na estimulação de uma discussão no âmbito da tradição metodológica da Sociologia e da Filosofia e, de certa forma, abriu espaço para a consolidação e institucionalização da "Sociologia da Religião", "Filosofia da Religião" e da "Ciência da Religião". 47

Ciência da Religião é uma disciplina empírica que busca uma investigação metódica da religião em todos os seus desdobramentos. ${ }^{48} \mathrm{Um}$ componente importante é o engajamento de seus representantes com os princípios da imparcialidade frente aos objetos de estudo. ${ }^{49}$ Não se interpela a "veracidade" ou a "propriedade" de uma fé religiosa. A partir da visão metodológica, religiões são complexos de essência solenemente congênere. É especialmente tal característica epistemológica que diferencia Ciência da Religião de Teologia.

A Ciência da Religião, antes de se tornar uma área de estudos independente, foi analisada a partir dos mais diversos olhares. William James, por exemplo, conhecido filósofo e psicólogo, estudou a religião sob essas perspectivas fazendo apologia à racionalidade da fé. O economista e sociólogo, Max Weber, se dedicou aos estudos da religião sob a ótica socioeconômica em seu consagrado ensaio "A ética protestante e o espírito do capitalismo" (1904-1906), que é aclamado como sendo a obra ilustrativa do século XX. Émile Durkheim, por sua vez, considerado o pai da sociologia moderna, lançou, em 1912, um dos mais relevantes estudos acerca da religião como evento social em seu trabalho "As formas elementares da vida religiosa" ${ }^{50}$ As obras e os autores citados devem ser lembrados, uma vez que marcam a investigação dos fenômenos partindo do pressuposto de uma Ciência da Religião genuína e não como extensão da Teologia ou da Filosofia. ${ }^{51}$

\section{O cenário da educação religiosa no Brasil atual}

O ensino religioso é um componente curricular que se presta à construção de valores morais na sociedade, especialmente através da educação e das técnicas pedagógicas. A moral cristã é um tema atual que reacende a discussão jurídica, legal e moral sobre o controle do

45 TUCKER, Ruth A. Até os Confins da Terra. São Paulo: Vida Nova, 1986, p. 73-75.

46 OLIVEIRA, 2001, p. 226.

47 OLIVEIRA, 2001, p. 171.

48 GRESCHAT, Hans-Jürgen. O que é ciência da religião? São Paulo: Paulinas, 2005, p. 23-24.

49 GRESCHAT, 2005, p. 24.

50 GRESCHAT, 2005, p. 24.

1 GRESCHAT, 2005, p. 19.

Protestantismo em Revista | São Leopoldo | v. 46, n. 01 | p. 98-109| Jan./jun. 2020

Disponível em: <http://periodicos.est.edu.br/index.php/nepp> 
Estado na liberdade de consciência e crença do cidadão brasileiro; os deveres da família e os deveres do Estado. ${ }^{52}$ Recentemente em discussão no Supremo Tribunal Federal, no julgamento da ADI 4439, foi considerado constitucional o ensino religioso nas escolas públicas, prestada e subsidiada pelo Estado, de forma confessional. ${ }^{53}$

Paradoxalmente, frentes religiosas afro e não cristãs ocupam seu lugar no Brasil de maneira crescente. $O$ debate sobre o ensino religioso reacende a questão sobre o que é democrático e igualitário, sobre prover direitos iguais aos tutelados pelo Estado. Assim, a questão de possibilitar ou impor uma religião ou um tipo de religião (cristã) no ensino parece exercer verdadeira segregação religiosa, ao passo que se verifica no Brasil religiões politeístas, monoteístas e ateístas que gozam do mesmo direito concedido constitucionalmente pela Constituição da República Federativa do Brasil. ${ }^{54}$

A exemplo dos religiosos protestantes que outrora se referiam a um grupo popular menos favorecido da sociedade, mas, que hoje se encontram nos grandes círculos do poder político e econômico do país, que estão em crescimento exponencial, segundo último censo do IBGE de 2010 de $61 \%$ em 10 anos, entre 2010, com 42.310 .000 evangélicos no Brasil, 22,2\% da população, enquanto o número de católicos apresentava decréscimo de mais de $1 \%$ ao ano. ${ }^{55}$ Igualmente, cabe ressaltar que estimativas apontam que em um futuro próximo, o número de evangélicos terá ultrapassado o número de católicos e é de se prever um crescimento de outras religiões como as africanas, espíritas e islâmicas. ${ }^{56}$

Hoje, temos um Brasil de fato de maioria Cristã, mas de múltiplas faces religiosas; há uma pluralidade religiosa, mesmo dentro do mundo evangélico; pode-se citar os novos movimentos pentecostais, denominados neopentecostais, que retomam o uso e abuso de símbolos como o sal grosso, óleo, copo de água, manto vermelho e algumas práticas mais recentes, que se tornam judaizantes, uma vez que traz velhos rituais de purificação e liturgia levítica. ${ }^{57}$ Nesse caso, para tais segmentos só não se deve idolatrar a imagem de gesso, porém vale reverenciar o portal de ouro e a construção de tabernáculos com pedras trazidas de Jerusalém e pilares de ouro maciço. ${ }^{58}$

\section{Conflitos religiosos diante da diversidade religiosa}

Dizer, assim, que o ensino religioso deva ser cristão nas escolas públicas, já não delimita o tema de grande diversidade e conflito doutrinário; nem, tampouco, garante a democracia e o direito de crença constitucionalmente previstos, os quais asseguram que esses devem se estender aos politeístas, monoteístas (inclusive aos não cristãos) e ateístas (porque é direito do cidadão não acreditar em qualquer divindade). ${ }^{59}$ Neste cenário é necessário se fazer algumas perguntas: É dever do Estado garantir o ensino religioso nas escolas públicas? Esse ensino deve ser confessional? Qual a posição da justiça brasileira sobre o assunto? Há outros modelos de ensino religioso propostos por pesquisadores da educação? Uma análise

\footnotetext{
FIGUEIREDO, 1996, p. 21.

SANTOS JÚNIOR, 2016, p. 33.

SANTOS JÚNIOR, 2016, p. 33.

SANTOS JÚNIOR, 2016, p. 34.

SANTOS JÚNIOR, 2016, p. 36.

SANTOS JÚNIOR, 2016, p. 17.

SANTOS JÚNIOR, 2016, p. 19.

SANTOS JÚNIOR, 2016, p. 19.
}

Protestantismo em Revista | São Leopoldo | v. 46, n. 01 | p. 98-109| Jan./jun. 2020

Disponível em: <http://periodicos.est.edu.br/index.php/nepp> 
crítica, teórica, prática e comparada sobre a questão foge às tendas da teologia e torna imprescindível o conhecimento numa abordagem interdisciplinar como se faz na ciência da religião. ${ }^{60}$

Desde 1965, com a autonomia das escolas, o ensino religioso vem perdendo sua função catequética, haja vista a consecução de valores morais e princípios autônomos da cultura do saber pedagógico. ${ }^{61}$ Com o crescente pluralismo religioso há uma necessidade cada vez mais crescente de o ensino religioso se adaptar e encontrar seu lugar numa dinâmica plural de conhecimento, ou a tendência desse será desaparecer das escolas e tornar-se um ensino de templo. ${ }^{62}$ Apesar de a Constituição Brasileira prever o ensino religioso obrigatório nas escolas, a sua viabilidade tem se tornado cada vez mais discutida entre o meio acadêmico, que torna a aplicação desta norma acompanhada da aplicação de princípios democráticos e de isonomia, para a consecução de um ensino verdadeiramente princípio lógico e acadêmico, porém não confessional.

\section{O dever do estado e a liberdade de crença}

É dever do Estado prover o ensino religioso nas escolas públicas do país? Esse dever é uma imposição de exercício ou uma obrigação de garantir? Porque garantir é diferente de impor, e, se assim dissermos, na interpretação do artigo 210 da Constituição da República Federativa do Brasil - CRFB ${ }^{63}$ - o Estado deve garantir o ensino, mas não impor a matrícula que por sua vez é facultativa. Mas que tipo de ensino deve garantir? Cristão? Não cristão?

A que se prestou o ensino religioso nas escolas públicas em nível fundamental, e quais foram os seus efeitos ou consequências? Se houve razões, quais foram as práticas? Ensino esse inicialmente e predominantemente catequético católico, e mais tarde denominado Cristão (abrangendo o ensino religioso evangélico). Porém, não há notícias de ensino religioso afro, islâmico ou espírita efetuados em nenhum momento nas unidades escolares. Se o valor do ensino religioso se preza à construção de valores morais da sociedade deve, nesse plano, ser perscrutados sua metodologia e conteúdo.

\section{O ensino religioso em tempos sombrios}

A sociedade justa com um ideal a ser perseguido tolera ou busca na religião valores morais a serem seguidos ou ideais próprios como construtores de seu pensamento moral. $A$ indução pelo caráter facultativo disponibilizado pelo Estado pode ampliar ou cercear essa liberdade à medida que pode impor ou, metodologicamente, expor de maneira isonômica as diferenças. ${ }^{64}$ Para uma abordagem imparcial, torna-se mister expor o problema do ensino

60 "No caso específico da Ciência da Religião, é consensual que a análise do seu campo complexo aança à medida que o estudo apropria-se do potencial heurístico das suas subáreas." PASSOS, João Décio. USARSKI, Frank. Compêndio de Ciências da Religião. Paulus: São Paulo, 2016, p. 18.

61 PASSOS, 2016, p. 18.

62 PASSOS, 2016, p. 18.

63 O Art. 210, da Constituição Federal diz: "Serão fixados conteúdos mínimos para o ensino fundamental, de maneira a assegurar formação básica comum e respeito aos valores culturais e artísticos, nacionais e regionais. § 1 ㅇ O ensino religioso, de matrícula facultativa [...]”. BRASIL, Constituição da República Federativa do Brasil, 1988.

64 PASSOS, 2016, p. 18.

Protestantismo em Revista | São Leopoldo | v. 46, n. 01 | p. 98-109| Jan./jun. 2020

Disponível em: <http://periodicos.est.edu.br/index.php/nepp> 
religioso numa discussão de interdisciplinaridade do direito, da religião e do ensino. Não há como supor que ensinar deva ser apenas impor ideias, mas, sobretudo, conduzir a construção de toda uma teia de novas ideias que só podem crescer num ambiente de ampla liberdade religiosa. ${ }^{65} \mathrm{O}$ ensino religioso facultativo e confessional nas escolas públicas é tolerado, embora em meio a inúmeros questionamentos que buscam a compreensão do caráter laico dos ensinamentos ministrados nas escolas públicas. ${ }^{66}$

O Estado não se separou totalmente da Igreja e isso de fato nunca aconteceu; o ser humano é um ser religioso. Como se preconizou a laicização, essa deve ser plural, multifacetada, da mesma maneira que a diversidade de símbolos e crenças. O Estado nessa eira é apenas garantidor desta liberdade plural de consciência e de crença e tem o dever de prestar o ensino religioso nas escolas públicas fundamentais que atenda a essa preceituação. ${ }^{67}$ A liberdade de consciência e a liberdade de crença permitem ao cidadão professar qualquer religião e até mesmo se abster de todas, princípio da não interferência do Estado na religião, laicidade. ${ }^{68}$ Sobre o significado de laico ensina Celso Lafer "laico significa tanto o que é independente de qualquer confissão religiosa quanto o relativo ao mundo da vida civil" 69 .

A Lei de Diretrizes e Bases da Educação ${ }^{70}$ prevê no seu art. 33 a facultatividade do ensino religioso na formação básica do cidadão, que assegura a diversidade religiosa brasileira, ao passo que a pluralidade religiosa vem reforçada pela mesma. No entanto, o debate é sobre a imiscuidade do Estado que é determinada pela própria constituinte no art. 210, parágrafo primeiro que dispõe:

Art. 210. Serão fixados conteúdos mínimos para o ensino fundamental, de maneira a assegurar formação básica comum e respeito aos valores culturais e artísticos, nacionais e regionais.

$\S 1$ o 0 ensino religioso, de matrícula facultativa, constituirá disciplina dos horários normais das escolas públicas de ensino fundamental.

Verifica-se que o cenário brasileiro é de uma laicidade sui generis, ou seja, uma laicidade que encontra oposição em sua concepção epistemológica no próprio ordenamento que confere ao Estado brasileiro o dever de oferecer ensino religioso, se opondo a ideia de laicidade que, por outro lado, garante e assegura a manifestação religiosa, mas não deve promovê-la, a rigor do artigo 19 da CRFB. No campo jurídico brasileiro a discussão teve um recente entendimento assentado pela Corte Suprema, no dia 27 de setembro de 2017, no julgamento da Ação Direta de Inconstitucionalidade ${ }^{71}$ proposta pela Procuradoria Geral da República que questionava o atual modelo confessional de ensino religioso nas escolas

65 FIGUEIREDO, 1996, p. 21.

66 SENA, Luiza (Org.). Ensino religioso e formação docente. São Paulo: Paulinas, 2006, p. 29.

67 FIGUEIREDO, 1996, p. 21.

68 Art. 5ㅇ, inciso VI "é inviolável a liberdade de consciência e de crença, sendo assegurado o livre exercício dos cultos religiosos e garantida, na forma da lei, a proteção aos locais de culto e a suas liturgias." De modo que temos a liberdade de crença ou consciência de um lado e a isenção de parte do Estado em se envolver nestes assuntos de forma ativa prevista no art. 19 da CRFB, mas apenas salvaguardando direitos já previstos.

69 LAFER, Celso. Estado Laico. In: Direitos Humanos, Democracia e República - Homenagem a Fábio Konder Comparato. São Paulo: Quartier Latin do Brasil, 2009, p. 226.

70 Lei n. 9.394 de 20 de dezembro de 1996. Art. 33 . Disponível em: http://www.planalto.gov.br/ccivil_03/leis/L9394.htm. Acesso em 10 fev. 2020.

71 ADI n. 4.439 do Supremo Tribunal Federal. Julgamento em 27 de setembro de 2017. Disponível em: http://portal.stf.jus.br/processos/detalhe.asp?incidente=3926392. Acesso em 10 fev. 2020.

Protestantismo em Revista | São Leopoldo | v. 46, n. 01 | p. 98-109| Jan./jun. 2020

Disponível em: <http://periodicos.est.edu.br/index.php/nepp> 
públicas. Nesse julgado restou o entendimento majoritário de que o ensino religioso confessional não ofende a laicidade do Estado.

Na ação, a PGR pedia a interpretação conforme a Constituição Federal ao dispositivo da Lei de Diretrizes e Bases da Educação - LDB (caput e parágrafos 1ำ e 2º, do artigo 33, da Lei 9.394/1996) e ao artigo 11, parágrafo 10 do acordo firmado entre o Brasil e a Santa Sé (promulgado por meio do Decreto 7.107/2010) para assentar que o ensino religioso nas escolas públicas não pode ser vinculado a religião específica e que fosse proibida a admissão de professores na qualidade de representantes das confissões religiosas. Ela sustentava que tal disciplina, cuja matrícula é facultativa, deve ser voltada para a história e a doutrina das várias religiões, ensinadas sob uma perspectiva laica.

\section{Conclusão}

Numa dinâmica de crescente necessidade de se examinar e reexaminar a metodologia do ensino religioso no Brasil à luz da ciência da religião, como resposta multidisciplinar e plural, existem posições no sentido de se adequar o ensino às necessidades plurais de crença, de modo a preservar o direito a esta liberdade. Contudo, o Brasil caminha enrijecido nas suas bases essencialmente cristãs consolidadas tanto pelo poder legislativo brasileiro, quanto referendado pela Corte Suprema.

A necessidade de um ensino essencialmente científico e plural é a resposta para reduzir as desigualdades que são ainda mais agravadas por um ensino religioso unicamente cristão. Dessa maneira, cabe ressaltar, que o estudo das religiões pode contribuir para um ensino religioso escolar mais humano e que colabore para uma sociedade mais igualitária, cidadã e que compreenda a riqueza da pluralidade cultural e religiosa.

\section{Referências}

ADI n. 4.439 do Supremo Tribunal Federal. Julgamento em 27 de setembro de 2017. Disponível em: http://portal.stf.jus.br/processos/detalhe.asp?incidente=3926392. Acesso em 10/02/2019.

BRASIL. Constituição Federal (1988). Disponível em: <http://www.planalto.gov.br/ccivil_03/Constituicao/Constituicao88.htm>. Acesso em: 20 fev. 2020.

BRASIL. Decreto Federal no 119-a de 1890. Disponível em: <http://www.planalto.gov.br/ccivil_03/decreto/1851-1899/d119-a.htm>. Acesso em: 01 mai. 2020.

CALMON, Pedro. História Social do Brasil: Espírito da Sociedade Colonial. São Paulo: Martins Fontes, 2010.

CHAUÍ, Marilena. Iniciação à Filosofia. 2. ed. São Paulo: Ática, 2014.

COX, Harvey. A Cidade Secular: a secularização e a urbanização na perspectiva teológica. Santo André -SP: Academia Cristã, 2015.

FIGUEIREDO, Anísia de Paulo. O ensino religioso no Brasil; tendências, conquistas e perspectivas. Petrópolis: Vozes, 1996.

Protestantismo em Revista | São Leopoldo | v. 46, n. 01 | p. 98-109| Jan./jun. 2020

Disponível em: <http://periodicos.est.edu.br/index.php/nepp> 
GEISLER, Norman L.; NIX, William E. A General Introduction to the Bible. Chicago: Hardcover, 1986.

GRESCHAT, Hans-Jürgen. O que é ciência da religião? São Paulo: Paulinas, 2005.

INSTITUTO DATAFOLHA DE PESQUISAS. Cenário religioso nacional. Disponível em: $<$ http://datafolha.folha.uol.com.br/opiniaopublica/2013/07/1314857-fatia-de-catolicos-e-amenor-em-duasdecadas.shtml>. Acesso em: 02 fev. 2020.

INSTITUTO DATAFOLHA DE PESQUISAS. Levantamento das religiões brasileiras. Disponível em: <http://datafolha.folha.uol.com.br/opiniaopublica/2013/09/138655096-mudanca-decenario-religioso.shtml>. Acesso em: 02 fev. 2020.

LAFER, Celso. Estado Laico. In: Direitos Humanos, Democracia e República - Homenagem a Fábio Konder Comparato. São Paulo: Quartier Latin do Brasil, 2009.

MONDIN, Battista. Curso de Filosofia. 10. ed. São Paulo: Paulus, 2006.

MORIN, Edgar. Introdução ao pensamento complexo. Porto Alegre: Sulina, 2005.

OLIVEIRA, Pérsio Santos. Introdução à Sociologia. São Paulo: Ática, 2001.

PASSOS, João. USARSKI, Frank (Org). Compêndio de Ciência da Religião. São Paulo: Paulus, 2016.

ROUSSEAU, Jean Jacques. Do contrato social. 2 ed. Leme: EDIJUR, 2013.

RUEDELL, Pedro. Evolução do Ensino Religioso nas escolas oficiais do Rio Grande do Sul. São Leopoldo: UNISINOS, 2007.

SANTOS JÚNIOR, Paulo Jonas dos. A Religiosa no Currículo de Filosofia do Estado do Espirito Santo e sua Prática Docente. 2016. 92 f. Dissertação (Mestrado) - Curso de Ciências das Religiões, Faculdade Unida de Vitória, Vitoria, 2016.

SANTOS JÚNIOR, Paulo Jonas dos; ROSA, André Luis da. Experiência religiosa: da Reforma Protestante ao avivamento pentecostal. Encontros Teológicos: Reforma ontem e hoje, Florianópolis, v. 31, n. 2, p.235-252, ago. 2016. Disponível em: <facasc.edu.br>. Acesso em: 05 abr. 2020.

SENA, Luiza (Org.). Ensino religioso e formação docente. São Paulo: Paulinas, 2006.

SYLVESTRE, Josué. Irmão vota em irmão: Os evangélicos, A Constituinte e a Bíblia. Brasília: Pergaminho, 1986.

TUCKER, Ruth A. Até os Confins da Terra. São Paulo: Vida Nova, 1986. 